\title{
Effect of storage temperature on quality of light and full-fat ice cream
}

\author{
J. R. Buyck, R. J. Baer, ${ }^{1}$ and J. Choi \\ Dairy Science Department, South Dakota State University, Brookings 57007-0647
}

\begin{abstract}
Ice cream quality is dependent on many factors including storage temperature. Currently, the industry standard for ice cream storage is $-28.9^{\circ} \mathrm{C}$. Ice cream production costs may be decreased by increasing the temperature of the storage freezer, thus lowering energy costs. The first objective of this research was to evaluate the effect of 4 storage temperatures on the quality of commercial vanilla-flavored light and full-fat ice cream. Storage temperatures used were $-45.6,-26.1$, and $-23.3^{\circ} \mathrm{C}$ for the 3 treatments and $-28.9^{\circ} \mathrm{C}$ as the control or industry standard. Ice crystal sizes were analyzed by a cold-stage microscope and image analysis at $1,19.5$, and 39 wk of storage. Ice crystal size did not differ among the storage temperatures of light and full-fat ice creams at 19.5 or 39 wk. An increase in ice crystal size was observed between 19.5 and 39 wk for all storage temperatures except $-45.6^{\circ} \mathrm{C}$. Coldness intensity, iciness, creaminess, and storage/stale off-flavor of the light and full-fat ice creams were evaluated at 39 wk of storage. Sensory evaluation indicated no difference among the different storage temperatures for light and full-fat ice creams. In a second study, light and full-fat ice creams were heat shocked by storing at $-28.9^{\circ} \mathrm{C}$ for $35 \mathrm{wk}$ and then alternating between -23.3 and $-12.2^{\circ} \mathrm{C}$ every $24 \mathrm{~h}$ for $4 \mathrm{wk}$. Heat-shocked ice creams were analyzed at 2 and 4 wk of storage for ice crystal size and were evaluated by the sensory panel. A difference in ice crystal size was observed for light and full-fat ice creams during heat-shock storage; however, sensory results indicated no differences. In summary, storage of light or full-fat vanilla-flavored ice creams at the temperatures used within this research did not affect quality of the ice creams. Therefore, ice cream manufacturers could conserve energy by increasing the temperature of freezers from -28.9 to $-26.1^{\circ} \mathrm{C}$. Because freezers will typically fluctuate from the set temperature, usage of $-26.1^{\circ} \mathrm{C}$ allows for a safety factor, even though storage at $-23.3^{\circ} \mathrm{C}$ did not affect ice cream quality.
\end{abstract}

Key words: ice cream, storage temperature, ice crystal, quality

Received October 5, 2010

Accepted January 14, 2011.

${ }^{1}$ Corresponding author: robert.baer@sdstate.edu

\section{INTRODUCTION}

Ice cream consists of at least 4 major discrete phases: ice crystals, air cells, fat globules, and liquid phase. It is a frozen mixture of a combination of components of milk, sweeteners, stabilizers, emulsifiers, and flavoring (Marshall et al., 2003). Ice cream quality is dependent on many factors, one being ice crystal size. Ice crystals form at the beginning of the freezing process. The freezing process involves rapid removal of heat while agitating vigorously to incorporate air, thus imparting the desirable smoothness and softness of the frozen product (Marshall et al., 2003). The faster the ice cream mix is frozen, placed into the final container, and sent through a blast freezer, the smaller the ice crystals are in the finished product. Smaller ice crystals $(<55 \mu \mathrm{m})$ in ice cream are more desirable to consumers, as the product is perceived to be less icy. Other factors that can contribute to iciness are low total solids content of the mix, low freezing point, high draw temperature, inadequate stabilizer, dull scraper blades, long storage time, and variable storage temperatures (Marshall and Arbuckle, 1996). Donhowe (1993) also showed that rapid cooling of ice cream during hardening resulted in smaller mean ice crystal size.

Ice crystals grow during storage when the ice cream warms: some of the ice crystals will melt and the free water is attracted to other crystals onto which it is frozen, creating larger ice crystals as the temperature decreases during storage (Marshall et al., 2003). A study by Donhowe and Hartel (1996) indicated that the rate of ice recrystallization is quite rapid at temperatures as high as $-5^{\circ} \mathrm{C}$. Their results showed that allowing ice cream to remain at $-5^{\circ} \mathrm{C}$ for $5 \mathrm{~d}$ resulted in an increase in ice crystal size from $45 \mu \mathrm{m}$ to $>110 \mu \mathrm{m}$, with the largest ice crystals growing larger than $200 \mu \mathrm{m}$. Studies by Berger and White (1979b) revealed that about $70 \%$ of ice crystals are $<55 \mu \mathrm{m}$ and that coarseness (iciness) of texture depends on the proportion of total ice crystals $>55 \mu \mathrm{m}$. An increase in total solids content of just a few percent (34 to $38 \%$ ) greatly increases the control over ice crystal growth (Keeney, 1979). Ice crystals are also influenced by ingredients and ingredient interactions. Fat content influences texture by decreasing the ice crystal size through mechanical obstruction and by producing a lubricating effect, causing a smooth sensation in the mouth (Goff et al., 1993). 
The maintenance of excellent body/texture and flavor during storage is an important factor in the successful marketing of ice cream. Conditions under which ice cream is held at the plant, in transit, and at the retail outlet should be well controlled if the quality of the product is to be maintained (Earl and Tracy, 1960). The International Dairy Foods Association has stated that any ice cream product stored at a temperature higher than $-28.9^{\circ} \mathrm{C}$ has incurred heat-shock (HS) damage and should not be sold at retail (International Dairy Foods Association, 1997). Several potential problems could arise during shipping and handling, any one of which could critically influence product quality. The most important of these problems is thermal abuse and its effect on ice crystals. Temperature fluctuations during shipping and handling of ice cream may be associated with changes in temperature of storage as the product moves from point to point during distribution (Marshall et al., 2003). The physical characteristics of ice cream, especially products with unstable texture, are particularly susceptible to fluctuating temperatures (Dolan et al., 1985).

Limited information exists in the literature on optimum freezer storage temperatures and ice cream quality. The first objective of this research was to determine if 4 storage temperatures $\left(-28.9^{\circ} \mathrm{C}\right.$ for the control or industry standard and $-23.3,-26.1$, and $-45.6^{\circ} \mathrm{C}$ for the 3 treatments) affected the quality of commercial vanilla flavored light (LT) and full-fat (FF) ice cream after 39 wk. This part of the study was designed to represent constant storage temperatures, simulating how a manufacturer would store ice cream before distribution. Composition, sensory evaluation, and ice crystal sizes of LT and FF ice creams were determined. A second objective was to simulate HS of LT and FF ice creams by cycling the freezer temperature from -23.3 to $-12.2^{\circ} \mathrm{C}$ every $24 \mathrm{~h}$ for $4 \mathrm{wk}$. This represented the effects of a consumer taking ice cream home and storing the ice cream in a self-defrost freezer. This research could assist with the conservation of energy in an ice cream plant and distribution centers if a higher freezer storage temperature can be used with no effect on ice cream quality.

\section{MATERIALS AND METHODS}

\section{Light and Full-Fat Ice Cream and Storage}

Commercial light (1.65-L sqround paperboard cartons) and FF (1.89-L rectangular paperboard cartons) vanilla-flavored ice creams (3 replicates for each of the 3 treatments and control) were obtained $1 \mathrm{~d}$ after production, held at $-28.9^{\circ} \mathrm{C}$, and transported via styrofoam shipping containers to holding freezers. Light and FF ice creams were stored for $1,19.5$, and $39 \mathrm{wk}$ in freezers at $-28.9^{\circ} \mathrm{C}$ (control or industry standard), $-23.3^{\circ} \mathrm{C}$ and $-26.1^{\circ} \mathrm{C}$ (temperatures selected to lower energy costs), and $-45.6^{\circ} \mathrm{C}$ (temperature selected for potential product quality improvement compared with industry standard) for the 3 treatment storage temperatures. Heat-shock simulation was also performed on each of the 3 replicates of LT and FF ice creams. Light and FF ice creams were stored in the $-28.9^{\circ} \mathrm{C}$ freezer for $35 \mathrm{wk}$ and then heat shocked (to simulate consumer abuse) by transferring them to a cabinet freezer that fluctuated temperatures between -23.3 and $-12.2^{\circ} \mathrm{C}$ every $24 \mathrm{~h}$.

\section{Light and Full-Fat Ice Cream Mix Analysis}

Ice cream mixes obtained from the manufacturer were analyzed in duplicate for fat by the Mojonnier method (Frank and Wehr, 2004) and for total N in duplicate by the Foss Kjeltec 2200 (Hoganas, Sweden) procedure (AOAC, 2002). Protein was determined by multiplying the total $\mathrm{N}$ by 6.38 . Mix ash content was determined in duplicate by a muffle furnace (Frank and Wehr, 2004). Total solids were determined in duplicate by a forced draft oven (Frank and Wehr, 2004). pH was measured with an Orion model $250 \mathrm{~A} \mathrm{pH}$ analyzer (Corning Inc., Corning, NY), and titratable acidity, expressed as percentage lactic acid, was determined in duplicate by using $0.10 \mathrm{~N} \mathrm{NaOH}$ to the phenolphthalein end point (Frank and Wehr, 2004). Freezing points of mixes were determined in duplicate by the osmometer method (Baer and Czmowski, 1985).

\section{Analysis of Ice Crystal Size}

Light and FF ice creams, slides, coverslips, utensils, and mounting medium were tempered to $-23.3^{\circ} \mathrm{C}$. Light and FF ice creams were sampled on the outer edge $(4 \mathrm{~cm})$ and the middle of the product. Two different locations were selected to take into account the possible effect of temperature variation during the hardening process. Light and FF ice creams were prepared by the squash mount method using a 1:1 mixture of 1-propanol and kerosene (Berger and White, 1979a). Prepared slides were placed above dry ice in an insulated styrofoam container and immediately transported to the Linkam LTS 120 large area heating/freezing thermoelectric stage with a Peltier element controlled by a Linkam PE94 temperature program in which the Eheim Professional II water circulator (Linkam) moved distilled water (to cool down the motor inside the cold stage) through it to maintain a programmed constant temperature of $-20^{\circ} \mathrm{C}$ (Linkam Scientific Ltd., Surrey, UK). A light microscope (Olympus BX 41, Olympus Corp., Tokyo, Japan) and camera (Insight Firewire 

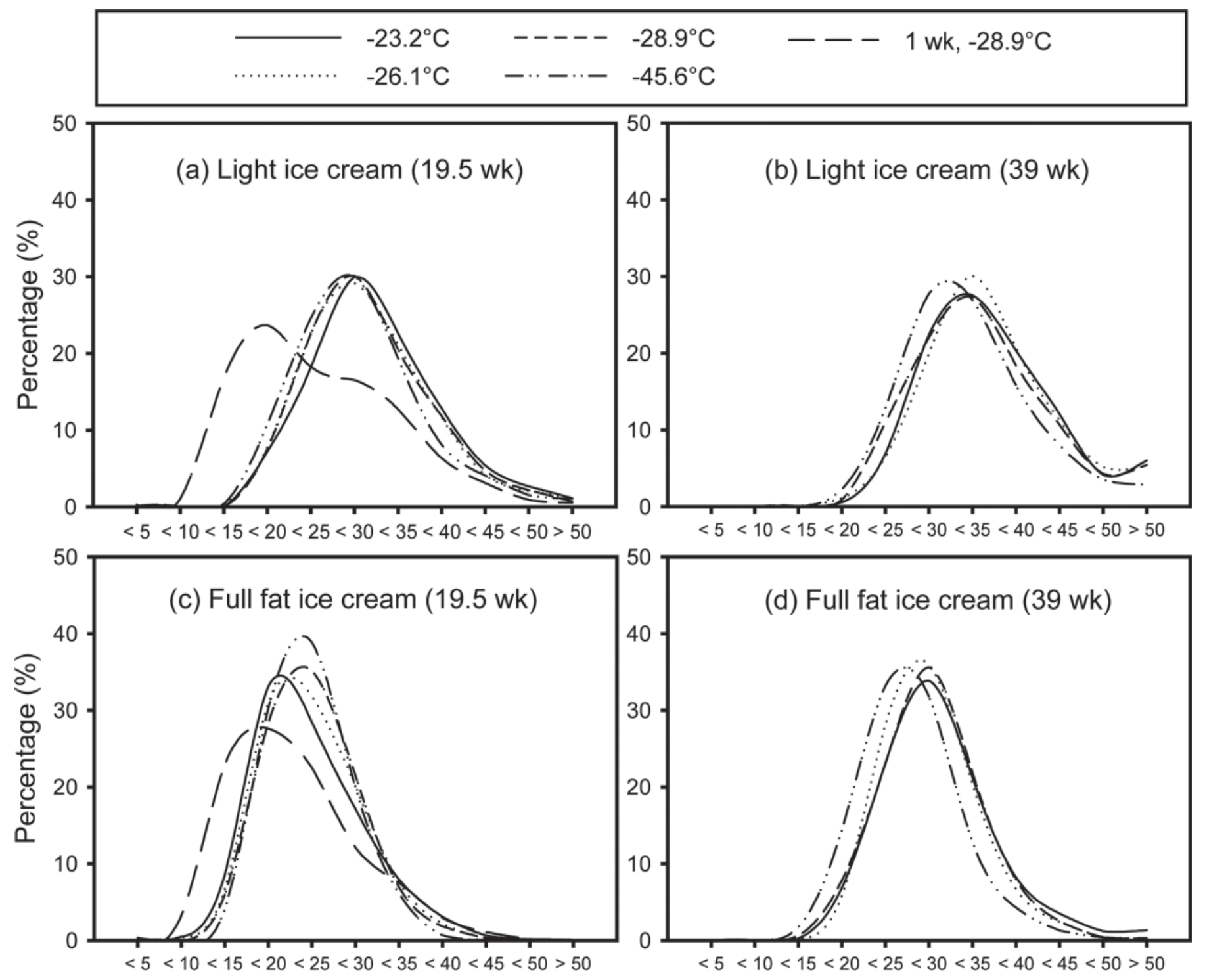

Diameter of ice crystal $(\mu \mathrm{m})$

Diameter of ice crystal $(\mu \mathrm{m})$

Figure 1. Ice crystal size distribution of light (LT) and full-fat (FF) ice creams at various storage temperatures for 19.5 and 39 wk. Ice crystal size distribution of LT and FF ice cream at $-28.9^{\circ} \mathrm{C}$ for $1 \mathrm{wk}$ was also included. Size distribution of ice crystals was expressed as percentage of the total number of ice crystals.

Spot 2 Megasample) were used to capture images at $100 \times$ magnification. Image Pro Plus 6.3 image analysis software (Media Cybernetics Inc., Bethesda, MD) was used to count the ice crystals (minimum of 250 ice crystals per sample) and size (area, perimeter, diameter maximum, diameter minimum, and diameter mean). Ice crystal size distribution $(\mu \mathrm{m})$ for LT and FF ice creams are given in Figures 1 and 2. Control and the 3 treatment storage temperatures for $\mathrm{LT}$ and $\mathrm{FF}$ ice creams (3 replicates) were evaluated for ice crystal size at $1,19.5$, and 39 wk of storage. In addition, the HS LT and FF ice creams were evaluated for ice crystal size at 2 and 4 wk of HS storage conditions.

\section{Sensory Evaluation}

A 7-member experienced sensory panel from South Dakota State University (Brookings) evaluated 3-digit randomly coded LT or FF ice cream samples for flavor and body/texture (Larmond, 1977; Patel et al., 2006). Scores were assigned to 4 attributes (iciness, coldness intensity, creaminess, and storage/stale flavor) on a 
Table 1. Light (LT) and full-fat (FF) ice cream mix and ice cream composition and characteristics ${ }^{1}$

\begin{tabular}{lccc}
\hline Item & $\begin{array}{c}\text { LT } \\
\text { mix }\end{array}$ & $\begin{array}{c}\text { FF } \\
\text { mix }\end{array}$ & SEM \\
\hline Fat $(\%)$ & $5.20^{\mathrm{b}}$ & $10.30^{\mathrm{a}}$ & 0.10 \\
Protein $(\%)$ & $3.99^{\mathrm{a}}$ & $2.97^{\mathrm{b}}$ & 0.07 \\
Ash $(\%)$ & $0.93^{\mathrm{a}}$ & $0.88^{\mathrm{b}}$ & 0.01 \\
Total solids $(\%)$ & $35.70^{\mathrm{b}}$ & $38.70^{\mathrm{a}}$ & 0.10 \\
pH & $6.92^{\mathrm{a}}$ & $6.50^{\mathrm{b}}$ & 0.02 \\
Titratable acidity $(\%)$ & $0.18^{\mathrm{a}}$ & $0.20^{\mathrm{a}}$ & 0.01 \\
Freezing point $\left({ }^{\circ} \mathrm{C}\right)$ & $-2.67^{\mathrm{a}}$ & $-2.65^{\mathrm{a}}$ & 0.03 \\
Draw temperature $\left({ }^{\circ} \mathrm{C}\right)$ & $-5.20^{\mathrm{a}}$ & $-4.95^{\mathrm{a}}$ & 0.30 \\
\hline
\end{tabular}

${ }^{\mathrm{a}, \mathrm{b}}$ Means in the same row without common superscripts differ $(P<$ $0.05)$.

${ }^{1}$ Least squares means of 3 replicates $(\mathrm{n}=3)$.

scale from 1 to $9(1=$ none, $5=$ definite, and $9=$ pronounced). Sensory evaluation was performed at 39 wk post-manufacture of LT and FF ice creams for all 4 constant storage temperatures. Heat-shocked LT or FF ice creams were evaluated at 2 and 4 wk of storage.

\section{Statistical Analysis}

For sensory analysis (Lea et al., 1997), a split plot design was used with whole-plot factor in a generalized randomized block design to evaluate effects due to mix (LT and FF), storage temperature $(-23.3,-26.1$, -28.9 , and $-45.6^{\circ} \mathrm{C}$ ), HS (with and without), and panelist (7 persons). For the ice crystal sizes, split plots in space and time (Steel and Torrie, 1980) were also used to evaluate effects of mix, storage temperature, storage time $(1,19.5$, and $39 \mathrm{wk}), \mathrm{HS}$, and location of ice crystal (middle and side). The location had no effect $(P>0.05)$ on ice crystal size, and therefore effect of location was not included in the model. Each effect was tested against appropriate error terms. Least squares means from each effect were compared using Scheffé's test $(P<0.05)$. All statistical analysis was conducted using PROC GLM in SAS (SAS Institute, 2001). All individual data $(33,134$ total number of ice crystals counted) were used to calculate the ice crystal size distribution in LT and FF ice creams (Figures 1 and 2).

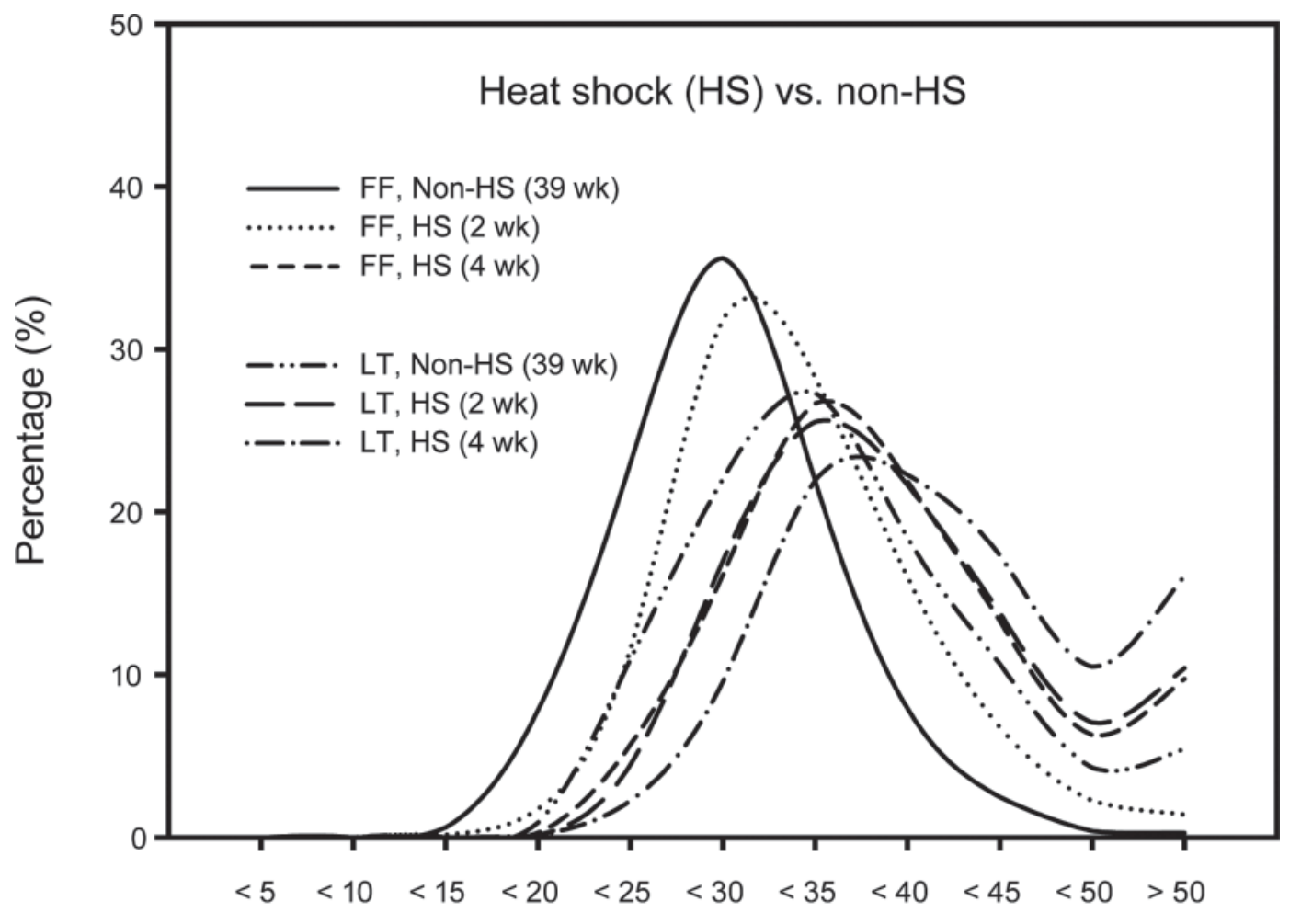

\section{Diameter of ice crystal $(\mu \mathrm{m})$}

Figure 2. Ice crystal size distribution of light (LT) and full-fat (FF) ice creams at $-28.9^{\circ} \mathrm{C}$ that received heat-shock (HS) for 2 or 4 wk storage or no HS. Changes in size distribution of ice crystals were expressed as percentage of the total number of ice crystals in LT and FF ice cream. 
Table 2. Sensory evaluation scores of light (LT) and full-fat (FF) ice creams stored at $-23.3,-26.1,-28.9$, or $-45.6^{\circ} \mathrm{C}$ at 39 wk postmanufacture

\begin{tabular}{|c|c|c|c|c|c|c|c|c|c|}
\hline $\begin{array}{l}\text { Sensory } \\
\text { criterion }^{2}\end{array}$ & \multicolumn{4}{|c|}{ LT ice cream } & \multicolumn{4}{|c|}{ FF ice cream } & SEM \\
\hline Iciness & $4.8^{\mathrm{a}}$ & $5.0^{\mathrm{a}}$ & $5.0^{\mathrm{a}}$ & $4.3^{\mathrm{a}}$ & $3.0^{\mathrm{b}}$ & $3.0^{\mathrm{b}}$ & $2.9^{\mathrm{b}}$ & $2.5^{\mathrm{b}}$ & 0.21 \\
\hline Coldness intensity & $5.2^{\mathrm{abc}}$ & $5.4^{\mathrm{a}}$ & $5.5^{\mathrm{a}}$ & $5.0^{\mathrm{ad}}$ & $4.0^{\mathrm{d}}$ & $4.1^{\mathrm{cd}}$ & $4.0^{\mathrm{bd}}$ & $3.9^{\mathrm{d}}$ & 0.22 \\
\hline Creaminess & $4.3^{\mathrm{c}}$ & $4.5^{\mathrm{c}}$ & $4.4^{\mathrm{c}}$ & $4.7^{\mathrm{bc}}$ & $5.8^{\mathrm{ab}}$ & $6.0^{\mathrm{a}}$ & $6.0^{\mathrm{a}}$ & $6.2^{\mathrm{a}}$ & 0.20 \\
\hline Storage/stale flavor & $2.1^{\mathrm{a}}$ & $1.9^{\mathrm{a}}$ & $2.0^{\mathrm{a}}$ & $1.9^{\mathrm{a}}$ & $1.9^{\mathrm{a}}$ & $1.7^{\mathrm{a}}$ & $2.0^{\mathrm{a}}$ & $1.7^{\mathrm{a}}$ & 0.11 \\
\hline
\end{tabular}

${ }^{\mathrm{a}-\mathrm{d}}$ Means in the same row without common superscripts differ $(P<0.05)$.

${ }^{1}$ Seven trained panelists were used and the number of replicates for LT and FF ice cream was $\mathrm{n}=3$.

${ }^{2}$ Scale where $1=$ none, $5=$ definite, and $9=$ pronounced.

\section{RESULTS AND DISCUSSION}

\section{Ice Cream Mix Composition and Characteristics}

Light and FF ice cream mix and ice cream composition and characteristics are given in Table 1. As expected, the LT ice cream mix had a lower $(P<0.05)$ percentage $(5.20 \%)$ of fat compared with the $\mathrm{FF}$ ice cream $(10.30 \%)$. Ice cream with higher fat content has been shown to have smaller ice crystal sizes (Keeney and Kroger, 1974). The total solids percentage was lower $(P<0.05)$ for LT ice cream mix compared with the FF ice cream mix, which was due to the higher percentage of fat in the FF ice cream. An ice cream mix with lower total solids has proportionately more water to freeze than a higher total solids mix hardened to the same storage temperature. Thus, ice cream mixes with high total solids content have a more desirable body/ texture (Marshall et al., 2003). Percentage total solids of the ice cream mix is directly related to ice crystal size distribution (Flores and Goff, 1999). Variations in total solids content of just a few percent greatly influence ice crystal growth (Keeney, 1979).

\section{Sensory Evaluation of Ice Creams}

Sensory evaluation scores of LT and FF ice creams at 39 wk post-manufacture are listed in Table 2. Analysis of variance (not shown) indicated that no interaction of mix $\times$ temperature was significant $(P>0.05)$. Temperature had an effect on iciness, and mix had an effect on iciness, cold intensity, and creaminess $(P<0.05)$. Multiple comparisons were made to see which temperatures were different, and results are shown in Table 2. It was found that all values within LT ice cream or all values within FF ice cream shared common superscripts, which means that storage temperature had no effect on sensory criteria within LT ice cream or within FF ice cream $(P>0.05)$. Generally, sensory scores were found to be better for FF ice cream than for LT ice cream. The FF ice cream had significantly $(P<0.05)$ lower iciness than LT ice cream. The FF ice cream stored at $-45.6^{\circ} \mathrm{C}$ had better $(P<0.05)$ sensory scores for iciness and creaminess than the LT ice creams.

The effect of HS on sensory evaluation scores of LT and $\mathrm{FF}$ ice creams stored at $-28.9^{\circ} \mathrm{C}$ for 39 wk was investigated. Analysis of variance (not shown) revealed no interaction between HS and mix on sensory criteria $(P>0.05)$. Heat shock was found to have a significant effect on iciness and creaminess $(P<0.05)$. Mix had a significant effect on iciness, coldness, creaminess, and storage/stale flavor $(P<0.05)$. Least squares means were used to make multiple comparisons, as shown in Table 3. Although no significant differences were observed between the non-HS and the HS treatments within LT ice cream or within FF ice cream (sensory scores within each ice cream mix shared common su-

Table 3. Effect of ice cream mix and heat shock (HS; no or yes) on sensory evaluation scores of light (LT) and full-fat (FF) ice creams at 39 wk post-manufacture ${ }^{1}$

\begin{tabular}{|c|c|c|c|c|c|}
\hline \multirow{2}{*}{$\begin{array}{l}\text { Sensory } \\
\text { criterion }^{2}\end{array}$} & \multicolumn{2}{|c|}{ LT ice cream } & \multicolumn{2}{|c|}{ FF ice cream } & \multirow[b]{2}{*}{ SEM } \\
\hline & No & Yes & No & Yes & \\
\hline Iciness & $5.0^{\mathrm{a}}$ & $5.4^{\mathrm{a}}$ & $2.9^{\mathrm{b}}$ & $3.8^{\mathrm{b}}$ & 0.25 \\
\hline Coldness intensity & $5.5^{\mathrm{ac}}$ & $5.5^{\mathrm{ac}}$ & $4.0^{\mathrm{b}}$ & $4.9^{\mathrm{bc}}$ & 0.24 \\
\hline Creaminess & $4.4^{\mathrm{bc}}$ & $4.1^{\mathrm{b}}$ & $6.0^{\mathrm{a}}$ & $5.2^{\mathrm{ac}}$ & 0.22 \\
\hline Storage/stale flavor & $2.0^{\mathrm{a}}$ & $2.1^{\mathrm{a}}$ & $2.0^{\mathrm{a}}$ & $1.9^{\mathrm{a}}$ & 0.10 \\
\hline
\end{tabular}


Table 4. Effect of light (LT) or full-fat (FF) ice cream, storage temperature $\left(-23.3,-26.1,-28.9\right.$, or $\left.-45.6^{\circ} \mathrm{C}\right)$, and storage time on ice crystal size $(\mu \mathrm{m})^{1}$

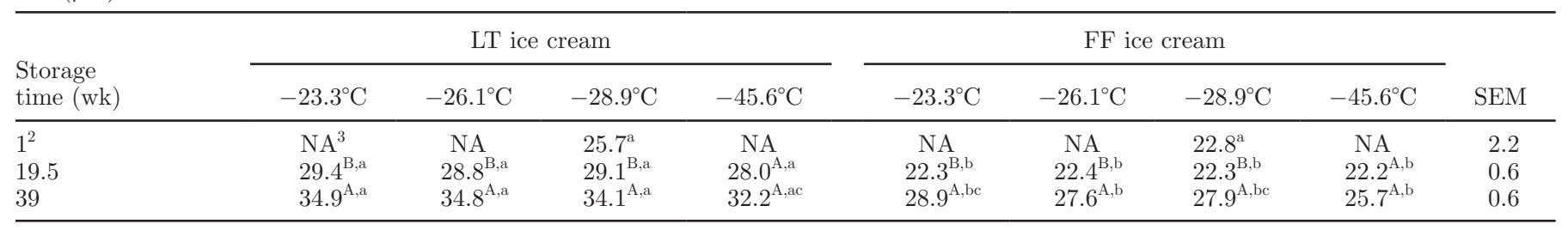

${ }_{\mathrm{A}, \mathrm{B}}$ Means in the same column without common superscripts differ $(P<0.05)$.

${ }^{\mathrm{a}-\mathrm{c}}$ Means in the same row without common superscripts differ $(P<0.05)$.

${ }^{1}$ Least squares means of 3 replicates $(\mathrm{n}=3)$.

${ }^{2}$ Ice crystal sizes at 1 wk were measured only at $-28.9^{\circ} \mathrm{C}$ for $\mathrm{LT}$ and $\mathrm{FF}$ ice cream. ANOVA for this comparison, therefore, did not include data from wk 19.5 and 39.5.

${ }^{3}$ Ice crystal size was not available and no measurements were made for $-23.3,-26.1$, and $-45.6^{\circ} \mathrm{C}$.

perscripts at $P<0.05)$, non-HS samples were found to have favorable sensory scores compared with HS. The FF ice cream gave better sensory scores than the LT ice cream.

\section{Effects on Ice Crystal Size}

The effects of mix, storage temperature, and storage time on ice crystal size are given in Table 4. Crystal size was not measured for storage temperatures at -23.3 , -26.1 , or $-45.6^{\circ} \mathrm{C}$ at $1 \mathrm{wk}$. The ice crystals at $1 \mathrm{wk}$ were larger in LT ice cream than in FF ice cream (Table 4), but this difference was not significant $(P>0.05)$. An ANOVA (not shown) was carried out to see if mix, storage temperature, and storage time influenced the size of ice crystals, and results are shown in Table 4. None of the interaction terms, mix $\times$ storage temperature, mix $\times$ storage time, and mix $\times$ storage temperature $\times$ storage time, were significant $(P>0.05)$. The effects of mix, storage temperature, and storage time were found to be significant $(P<0.05)$. However, no difference $(P>0.05)$ was seen among the storage temperatures at 19.5 or 39 wk for LT and FF ice creams. As storage time was extended from 19.5 to $39 \mathrm{wk}$, crystal size increased, but ice cream made with $\mathrm{FF}$ mix had smaller crystals of 25.7 to $28.9 \mu \mathrm{m}$ at 39 wk. A difference $(P$ $<0.05$ ) between storage time at 19.5 and 39 wk was observed, except for storage at $-45.6^{\circ} \mathrm{C}$.
Effects of LT or FF ice cream and HS on ice crystal size are given in Table 5. Analysis of variance (not shown) shows that the interaction of mix $\times$ HS was not significant $(P>0.05)$, and mix and HS had a significant effect on the size of ice crystals $(P<0.05)$. When LT ice cream was exposed to temperature cycling from 2 to $4 \mathrm{wk}$, the size of ice crystals increased from 37.3 to $40.3 \mu \mathrm{m}$, which was much greater than that $(34.2$ $\mu \mathrm{m})$ in non-HS. A similar trend for FF ice cream was observed, but crystals were smaller than that in LT ice cream. This showed that ice crystals grew as the LT and $\mathrm{FF}$ ice creams were stored during HS abuse.

\section{Ice Crystal Size Distribution of Ice Creams}

The distribution in ice crystal size for LT and FF ice creams at 19.5 and $39 \mathrm{wk}$ is shown in Figure 1. As indicated in Figure 1a, at all 4 storage temperatures, LT ice cream had larger ice crystals at 19.5 wk postmanufacture than the initial ice cream (evaluated at 1 wk post-manufacture). Figure 1b illustrates the growth of ice crystals in LT ice cream during 39 wk of storage. The lowest storage temperature $\left(-45.6^{\circ} \mathrm{C}\right)$ had a smaller mean ice crystal size, and samples stored at $-26.1^{\circ} \mathrm{C}$ had a slightly higher mean ice crystal size than those at storage temperatures of -23.2 and $-28.9^{\circ} \mathrm{C}$. Figure 1c indicates that FF ice cream followed a similar pattern as LT ice cream. All 4 storage temperatures of

Table 5. Effect of light (LT) or full-fat (FF) ice cream and heat shock (HS; duration of temperature cycling of 0,2 , or $4 \mathrm{wk})$ on ice crystal size $\mathrm{e}^{1,2}$

\begin{tabular}{|c|c|c|c|c|c|c|c|}
\hline \multirow[b]{2}{*}{ Item } & \multicolumn{3}{|c|}{ LT ice cream } & \multicolumn{3}{|c|}{ FF ice cream } & \multirow[b]{2}{*}{ SEM } \\
\hline & $0^{3}$ & 2 & 4 & 0 & 2 & 4 & \\
\hline Ice crystal size $(\mu \mathrm{m})$ & $34.2^{\mathrm{bc}}$ & $37.3^{\mathrm{ab}}$ & $40.3^{\mathrm{a}}$ & $27.9^{\mathrm{d}}$ & $31.7^{\mathrm{c}}$ & $36.9^{\mathrm{b}}$ & 0.61 \\
\hline
\end{tabular}


FF ice cream produced larger ice crystals at $19.5 \mathrm{wk}$ post-manufacture than the initial ice cream evaluated at 1 wk post-manufacture. Compared with Figure 1c, Figure 1d indicates a growth in ice crystal diameter from 19.5 to 39 wk post-manufacture. The lowest storage temperature $\left(-45.6^{\circ} \mathrm{C}\right)$ resulted in more smaller ice crystals than the highest 3 temperatures. The other 3 storage temperatures, $-28.9,-26.1$, and $-23.2^{\circ} \mathrm{C}$, had similar distribution percentages for ice crystal size. Ice crystal size distribution of LT and FF HS and nonHS ice creams at 2 and $4 \mathrm{wk}$ of storage are given in Figure 2. As expected, non-HS LT and FF ice creams had smaller ice crystals than the HS ice creams at both 2 and 4 wk of storage. Future research should evaluate storage temperatures above $-23.3^{\circ} \mathrm{C}$ to verify the effects of warmer temperatures than those tested in this study. In addition, evaluation of other flavored ice creams with inclusions and variegates and novelty items could determine the effects of different storage temperatures on their quality.

\section{CONCLUSIONS}

Light ice cream had lower fat and total solids than FF ice cream, which contributed to the LT ice cream having larger ice crystals than FF ice cream after storage for 39 wk. Storing LT and FF ice creams at higher temperatures $\left(-23.3\right.$ and $\left.-26.1^{\circ} \mathrm{C}\right)$ than the industry standard of $-28.9^{\circ} \mathrm{C}$ showed no difference in the quality of ice cream. Storing LT and FF ice creams at $-45.6^{\circ} \mathrm{C}$ did not show any benefit compared with the industry standard temperature of $-28.9^{\circ} \mathrm{C}$. Although LT and FF ice creams showed an increase in ice crystal size over storage time, the sensory evaluation results did not show any differences among the different storage temperatures. Light and FF ice creams showed an increase in ice crystal size during HS abuse. Storing commercial LT and FF vanilla-flavored ice creams at the storage temperatures used within this research did not affect the quality of the ice cream. Thus, ice cream manufacturers could conserve energy by increasing the temperature of freezers from -28.9 to $-26.1^{\circ} \mathrm{C}$. Freezers will fluctuate from the set temperature; therefore, using $-26.1^{\circ} \mathrm{C}$ allows for a safety factor. However, if freezers were set at $-23.3^{\circ} \mathrm{C}$, and temperature fluctuations resulted in temperatures warmer than the set point, product quality might be diminished.

\section{ACKNOWLEDGMENTS}

This work in part was supported by the South Dakota Agricultural Experiment Station (Brookings).

\section{REFERENCES}

AOAC. 2002. Method 33.2.11. Chapter 33. Pages 10-11 in Official Methods of Analysis. Vol. II. 17th ed. Association of Official Analytical Chemists Int., Gaithersburg, MD.

Baer, R. J., and T. P. Czmowski. 1985. Use of the osmometer for quality control of ice cream mix. J. Dairy Sci. 48:976-978.

Berger, K. G., and G. W. White. 1979a. Ice cream. Pages 499-530 in Food Emulsions. S. Friberg, ed. Marcel Dekker Inc., New York, NY.

Berger, K. G., and G. W. White. 1979b. Ice cream. Page 499 in Food Microscopy. J. G. Vaughan, ed. Academic Press, London, UK.

Dolan, K. D., R. P. Singh, and J. H. Wells. 1985. Evaluation of timetemperature related quality changes in ice cream during storage. J. Food Process. Preserv. 9:253-271.

Donhowe, D. P. 1993. Ice recrystallization in ice cream and ice milk. $\mathrm{PhD}$ Thesis. University of Wisconsin-Madison, Madison.

Donhowe, D. P., and R. W. Hartel. 1996. Recrystallization of ice in ice cream during controlled accelerated storage. Int. Dairy J. 6:1191-1208.

Earl, F. A., and P. H. Tracy. 1960. The importance of temperature in the storage of ice cream. Ice Cream Trade J. 56(11):36, 37, 40, $42,78-80$

Flores, A. A., and H. D. Goff. 1999. Ice crystal distributions in dynamically frozen model solutions and ice cream as affected by stabilizers. J. Dairy Sci. 82:1399-1407.

Frank, J. F., and H. M. Wehr. 2004. Pages 364-366, 380-382, 427-433, and 449-451 in Standard Methods for the Examination of Dairy Products. 17th ed. Am. Public Health Assoc., Washington, DC.

Goff, H. D., K. B. Caldwell, D. W. Stanley, and T. J. Maurice. 1993. The influence of polysaccharides on the glass transition in frozen sucrose solutions and ice cream. J. Dairy Sci. 76:1268-1277.

International Dairy Foods Association. 1997. Page 6 in Ice Cream and Frozen Novelties Code of Recommended Handling Practices. Washington, DC.

Keeney, P. G. 1979. Confusion over heat shock. Food Eng. 51:116118

Keeney, P. G., and M. Kroger. 1974. Frozen dairy products. Pages 879-913 in Fundamentals of Dairy Chemistry. 2nd ed. B. H. Webb, A. H. Johnson, and J. A. Alford, ed. The AVI Publ. Co., Inc., Westport, CT.

Larmond, E. 1977. Laboratory Methods for Sensory Evaluation of Food. Agric. Can. Publ. No. 1637. Canada Dept. Agric., Ottawa, ON, Canada.

Lea, P., T. Naes, and M. Rodbotten. 1997. More complex ANOVA situations. Pages 46-55 in Analysis of Variance for Sensory Data. John Wiley \& Sons Ltd., London, UK.

Marshall, R. T., and W. S. Arbuckle. 1996. Pages 263-268 in Ice Cream. 5th ed. Chapman and Hall, Int. Thompson Publ., New York, NY.

Marshall, R. T., H. D. Goff, and R. W. Hartel. 2003. Pages 1-5, 11, 44, 171, 173, 241, 250, 305, and 309 in Ice Cream. 6th ed. Kluwer Academic/Plenum Publ., New York, NY.

Patel, M. R., R. J. Baer, and M. R. Acharya. 2006. Increasing the protein content of ice cream. J. Dairy Sci. 89:1400-1406.

SAS Institute. 2001. SAS User's Guide: Statistics. Version 9.1. SAS Inst. Inc., Cary, NC.

Steel, R. G. D., and J. H. Torrie. 1980. Analysis of variance IV: Splitplot designs and analysis. Pages 377-400 in Principles and Procedures of Statistics. 2nd ed. McGraw-Hill Book Co., New York, NY. 